\title{
Induction of genotoxicity after subchronic treatment with 4-nonylphenol in blood cells from gill and kidney and restoration of DNA integrity after recovery by Channa punctatus
}

\author{
Madhu Sharma* \\ Department of Fisheries, CSKHPKV, Palampur (H. P), India \\ Pooja Chadha \\ Department of Zoology, Guru Nanak Dev University, Amritsar-143005( Punjab), India \\ *Corresponding author. E-mail: madhu.srma@gmail.com
}

\section{Article Info}

DOI:10.31018/jans.v11i2.2099

Received: April 29, 2019

Revised: June 2, 2019

Accepted: June 7, 2019

\section{How to Cite}

Sharma, M. and Chadha, P. (2019). Induction of genotoxicity after subchronic treatment with 4nonylphenol in blood cells from gill and kidney and restoration of DNA integrity after recovery by Channa punctatus. Journal of Applied and Natural Science, 11(2): 478- 485 https:// doi.org/10.31018/ jans.v11i2.2099

Keywords: Aberrant cells; Genotoxicity; Micronucleated cells; 4-Nonylphenol; Recovery

\section{INTRODUCTION}

In the world market thousands of chemicals are entering annually, and most of them are hazardous to the aquatic environment. Pollution of the aquatic ecosystems is globally recognized as a potential threat to all animals, including humans as well as aquatic organisms that interact with aquatic environment (Biney et al., 1987). In the developing countries, $90-95 \%$ of all sewage and $70 \%$ of industrial wastes are dumped untreated into surface water (Obiakor et al., 2012). In India, almost all the water bodies are found to be contaminated with one or another industry and ample evidences are available regarding the mismanagement of industrial waste (Jadhav and Singare, 2015; Singare and Dhabarde, 2014).

The history of environmental chemical pollutants is dominated by several chemical compounds of different characteristics such as polycyclic aromatic hydrocarbons, polychlorinated insecticides, polychlorinated biphenyl, synthetic surfactants, and heavy metals, and so on. In the early 1980s, it became evident that alkylphenolic compounds are significant environmental pollutants, these are derived from non ionic surfactants of alkyphenol polyethoxylate (Giger et al., 2009). Subsequently, nonylphenol ethoxylates and their metabolites became a major focus of environmental research. Nonylphenol ethoxylates are cost-effective surfactants used globally in industrial, institutional, commercial, and household applications such as detergents, antistatic agents, emulsifiers, demulsifiers, wetting and dispersing agents, and solubilizers (Fiege et al., 2000; Lorenc et al., 2003; Soares et al., 2008; Vincent and Sneddon, 2009). Furthermore, these chemicals are being used in the products we use in our daily life, such as shampoos, deodorants, skin care products, plastic items, and so on (Cowan-Ellsberry et al., 2014). Due to extensive use of such chemical derivatives substantial quantities of nonylphenol ethoxylates reach sewage treatment works where they are only partially degraded to nonylphenol (NP) due to microbial action (Ahel et al., 1994; Shao et al., 2003; Johnson et al., 2005; Koh et al., 2005; Vazquez-Duhalt et al., 2005; Nakada et al., 2006; Ngugen et al., 2011) and then via food-chain accumulates in the bodies of biota.

NP that can migrate from food plastic and drinking water is found to be toxic to different biota (Hamlin et al., 2015, Priac et al., 2014). Since its discovery, the production of nonylphenol has increased exponentially by as much as 100-500 million pounds every year and meet the definition of high production volume chemical (EPA, 2010). World- 
wide production of NP is approximately 500,000 tons, out of which $60 \%$ is finally discharged to water bodies (Ying et al., 2002). The European Union has included NP and their derivatives in the list of priority hazardous substances (Directive 2000/60/EC 2000). Micronucleus test is one used commonly for genotoxicity assessment in fish. Micronucleus assay has advantages over other tests as it is technically easier to use, cheaper, and less time-consuming (Galindo et al., 2014; Bhatnagar et al., 2016).

Gill is the organ for respiration, and it plays a role in osmoregulation and nitrogen excretion processes and is particularly sensitive to adverse environmental conditions. This is the organ that comes into direct contact with the pollutant, it also has a large interface area between external and internal environments of the fish. A number of studies have documented the toxic effect of nonylphenol ethoxylate over fish gill and have concluded that gill is particularly sensitive for the surfactants (Cox, 1996; Sandbacka et al., 2000; Wu et al., 2005). Kidney play an important role in maintaining osmotic homeostasis. It is the main organ of homeostasis and filtration. Because water reabsorption takes place in the distal tubule, so renal tissue is in constant exposure to chemicals and the risk of damage to the tissue is high.

C. punctatus is distributed throughout India. This species is of commercial importance due to its high food value, easy maintenance, and availability throughout the year (Talukdar et al., 2016). Moreover $C$. punctatus has been used in fundamental research and considered as an excellent model for toxicological studies (Javed et al., 2016; Sharma and Chadha 2017). So keeping all these things in mind, this study aimed at increasing the knowledge and understanding about the toxic effects of 4-NP toward an aquatic vertebrates model Channa punctatus after sub chronic exposure and provide an in-depth view into the efficiency of DNA repair system in C. punctatus.

\section{MATERIALS AND METHODS}

Chemical: 4-nonylphenol used in the present study was obtained from Himedia (India). A stock solution was prepared in ethanol. The stock was prepared so that the concentration of ethanol remains constant in all the treatments.

Experimental fish and toxicity bioassay: To determine the 96-hour $L_{50}$ value of 4nonylphenol, acute toxicity bioassay was conducted in a static system in the laboratory the test solution was changed every day to ensure that the chemical level stayed the same throughout the test period. The 96-hours $\mathrm{LC}_{50}$ value of 4nonylphenol was determined as $1.27 \mathrm{mg} / \mathrm{l}$ for $C$. punctatus (Sharma et al., 2014), following the probit analysis method as described by Finney (1971). Safe application rate (SAR) was calculated using the formula given by Basak and Konar (1977). After calculating the SAR three sublethal concentrations were decided, which were $1 / 10^{\text {th }}$ $(0.15 \mathrm{mg} / \mathrm{l}), 1 / 15^{\text {th }}(0.10 \mathrm{mg} / \mathrm{l})$ and $1 / 20^{\text {th }}(0.07 \mathrm{mg} / \mathrm{l})$ of the SAR.

$\mathrm{SAR}=\mathrm{LC}_{0} \times \mathrm{LC}_{100} / \mathrm{LC}_{50}$

In-vivo exposure experiment: The fish specimens (40 no) were exposed to the three aforementioned test concentrations of 4-nonylphenol and in tap water (10 no) and ethanol (10 no) in a static renewal system with the change of test water every day to maintain concentration consistently. The exposure was continued up to 90 days, and blood sample were taken at the intervals of 30,60 , and 90 days at the rate of five different fish per interval. The specimens maintained in tap water were considered as negative control and those in ethanol as a positive control. After 90 days of exposure fish were kept in water without 4nonylphenol for 30 days and at the end of 30 days recovery was ascertained.

Micronucleus assay: For each experimental group as well as for controls drops of blood taken from gill and kidney were smeared onto clean slides. Slides were then fixed in absolute ethanol for $10 \mathrm{~min}$ and stained with $10 \%$ Giemsa (Palhares and Grisolia, 2002). In each group, 1000 erythrocytes were counted under a binocular microscope (Olympus) using a 100x oil immersion lens. Cells were scored for micronucleated cells (MNC) and aberrant cells (AC). Different nuclear and cytoplasmic abnormalities like nuclear bud, notched nucleus, nuclear and cytoplasmic bridge, vacuolated nucleus and cytoplasm, deformed nuclei, caryolysis and swelled cells were considered as aberrant cells.

Statistical analysis: The results are expressed as mean $\pm S$.E. to study the significance of the difference in the frequency of micronucleated and altered erythrocytes among treated and control group one-way analysis of variance (ANOVA) followed by Tukey-HSD test were conducted with the help of SPSS.

\section{RESULTS}

MNC and AC frequency in blood cells from the gill and kidney: $M N C$ and $A C$ frequencies in blood cells from gill and kidney tissue of $C$. punctatus are presented in Table 1 and 2 respectively. All the concentrations at their respective durations evoked significant DNA damage in gill tissue when compared with control groups (Table 1). After 90 days exposure to 4-NP, the highest genotoxicity $(4.45 \%)$ in gill erythrocytes was found in the group treated with $4-\mathrm{NP}$ at $0.15 \mathrm{mg} / \mathrm{l}$ concentration. The time-dependent increase was observed at all concentrations and the highest effect was seen at the highest duration of exposure. In blood cells from gill tissue, $A C$ frequency increased from $4.38 \%$ in the control group to $63.71 \%$ (highest effect) in fish 
Table 1. Frequency of percent $M N C$ and $A C$ in blood cells from gill of fish $C$. punctatus after exposure to different concentrations of 4-NP for 30, 60 and 90 days.

\begin{tabular}{lllll}
\hline & & 30 days & $\mathbf{6 0}$ days & 90 days \\
\hline MNC & Control & $0.03 \pm 0.002^{\mathrm{a}, \mathrm{p}}$ & $0.03 \pm 0.01^{\mathrm{a}, \mathrm{p}}$ & $0.04 \pm 0.002^{\mathrm{a}, \mathrm{p}}$ \\
& Ethanol & $0.08 \pm 0.01^{\mathrm{a}, \mathrm{p}}$ & $0.07 \pm 0.003^{\mathrm{a}, \mathrm{p}}$ & $0.10 \pm 0.008^{\mathrm{a}, \mathrm{p}}$ \\
& $0.07 \mathrm{mg} / \mathrm{l}$ & $0.65 \pm 0.08^{\mathrm{a}, \mathrm{q}}$ & $0.75 \pm 0.12^{\mathrm{a}, \mathrm{p}}$ & $1.42 \pm 0.05^{\mathrm{b}, \mathrm{q}}$ \\
$\mathrm{AC}$ & $1.36 \pm 0.08^{\mathrm{a}, \mathrm{r}}$ & $1.94 \pm 0.29^{\mathrm{a}, \mathrm{q}}$ & $3.37 \pm 0.09^{\mathrm{b}, \mathrm{r}}$ \\
& $0.10 \mathrm{mg} / \mathrm{l}$ & $1.85 \pm 0.20^{\mathrm{a}, \mathrm{r}}$ & $3.26 \pm 0.26^{\mathrm{b}, \mathrm{r}}$ & $4.45 \pm 0.28^{\mathrm{c}, \mathrm{s}}$ \\
& $0.15 \mathrm{mg} / \mathrm{l}$ & $4.46 \pm 0.11^{\mathrm{a}, \mathrm{p}}$ & $4.35 \pm 0.08^{\mathrm{a}, \mathrm{p}}$ & $4.38 \pm 0.06^{\mathrm{a}, \mathrm{p}}$ \\
& Control & $5.12 \pm 0.06^{\mathrm{a}, \mathrm{p}}$ & $5.37 \pm 0.014^{\mathrm{b}, \mathrm{p}}$ & $5.39 \pm 0.003^{\mathrm{b}, \mathrm{p}}$ \\
& Ethanol & $13.35 \pm 1.13^{\mathrm{a}, \mathrm{q}}$ & $26.39 \pm 0.49^{\mathrm{b}, \mathrm{q}}$ & $28.8 \pm 0.89^{\mathrm{b}, \mathrm{q}}$ \\
& $0.07 \mathrm{mg} / \mathrm{l}$ & $35.80 \pm 1.75^{\mathrm{a}, \mathrm{r}}$ & $31.80 \pm 0.89^{\mathrm{a}, \mathrm{r}}$ & $50.31 \pm 2.05^{\mathrm{b}, \mathrm{r}}$ \\
& $0.10 \mathrm{mg} / \mathrm{l}$ & $38.1 \pm 0.86^{\mathrm{a}, \mathrm{r}}$ & $50.53 \pm 1.44^{\mathrm{b}, \mathrm{s}}$ & $63.71 \pm 0.84^{\mathrm{c}, \mathrm{s}}$ \\
\hline
\end{tabular}

The values given as mean \pm standard error. Different letters $(a, b, c)$ between the columns are significantly different (Tukey's test, $p \leq 0.01$ ) and signify the effect of duration of exposure at each concentration. Similarly, different letters $(p, q, r, s)$ within the columns are significantly different (Tukey's test, $p \leq 0.01$ ) and signify the effect of different concentrations of 4-nonylphenol at the same time interval.

Table 2 Frequency of percent MNC and AC in blood cells from kidney of fish $C$. punctatus after exposure to different concentrations of 4-NP for 30,60 and 90 days.

\begin{tabular}{lllll}
\hline & & $\mathbf{3 0}$ days & $\mathbf{6 0}$ days & $\mathbf{9 0}$ days \\
\hline MNC & Control & $0.2 \pm 0.005^{\mathrm{a}, \mathrm{p}}$ & $0.21 \pm 0.005^{\mathrm{a}, \mathrm{p}}$ & $0.21 \pm 0.008^{\mathrm{a}, \mathrm{p}}$ \\
& Ethanol & $0.22 \pm 0.012^{\mathrm{a}, \mathrm{p}}$ & $0.24 \pm 0.006^{\mathrm{a}, \mathrm{p}}$ & $0.23 \pm 0.005^{\mathrm{a}, \mathrm{p}}$ \\
& $0.07 \mathrm{mg} / \mathrm{l}$ & $0.57 \pm 0.03^{\mathrm{a}, \mathrm{q}}$ & $0.86 \pm 0.06^{\mathrm{b}, \mathrm{q}}$ & $1.26 \pm 0.02^{\mathrm{c}, \mathrm{q}}$ \\
$\mathrm{AC}$ & $0.98 \pm 0.003^{\mathrm{a}, \mathrm{r}}$ & $1.77 \pm 0.19^{\mathrm{b}, \mathrm{r}}$ & $2.14 \pm 0.19^{\mathrm{b}, \mathrm{r}}$ \\
& $0.10 \mathrm{mg} / \mathrm{l}$ & $1.30 \pm 0.16^{\mathrm{a}, \mathrm{r}}$ & $1.75 \pm 0.11^{\mathrm{a}, \mathrm{r}}$ & $2.6 \pm 0.22^{\mathrm{b}, \mathrm{r}}$ \\
& $0.15 \mathrm{mg} / \mathrm{l}$ & $7.95 \pm 0.13^{\mathrm{a}, \mathrm{p}}$ & $7.99 \pm 0.02^{\mathrm{a}, \mathrm{p}}$ & $7.95 \pm 0.04^{\mathrm{a}, \mathrm{p}}$ \\
& Control & $7.96 \pm 0.13^{\mathrm{a}, \mathrm{p}}$ & $7.99 \pm 0.02^{\mathrm{a}, \mathrm{p}}$ & $7.95 \pm 0.04^{\mathrm{a}, \mathrm{p}}$ \\
& Ethanol & $23.71 \pm 0.90^{\mathrm{a}, \mathrm{q}}$ & $30.87 \pm 4.97^{\mathrm{ab}, \mathrm{q}}$ & $38.87 \pm 0.57^{\mathrm{b}, \mathrm{q}}$ \\
& $0.07 \mathrm{mg} / \mathrm{l}$ & $29.26 \pm 0.46^{\mathrm{a}, \mathrm{r}}$ & $38.26 \pm 0.56^{\mathrm{b}, \mathrm{qr}}$ & $55.32 \pm 0.54^{\mathrm{c}, \mathrm{r}}$ \\
& $0.10 \mathrm{mg} / \mathrm{l}$ & $33.7 \pm 2.27^{\mathrm{a}, \mathrm{r}}$ & $46.68 \pm 0.63^{\mathrm{b}, \mathrm{r}}$ & $53.38 \pm 1.76^{\mathrm{b}, \mathrm{r}}$ \\
\hline
\end{tabular}

The values given as mean \pm standard error. Different letters $(a, b, c)$ between the columns are significantly different (Tukey's test, $p \leq 0.01$ ) and signify the effect of duration of exposure at each concentration. Similarly, different letters $(p, q, r, s)$ within the columns are significantly different (Tukey's test, $p \leq 0.01$ ) and signify the effect of different concentrations of 4-nonylphenol at the same time interval.

Table 3. Frequency of percent micronucleated cell and aberrant cells in blood cells from gill and kidney tissue of fish C. punctatus after exposure to different concentrations of 4-NP for 90 days and after 30 days recovery.

\begin{tabular}{|c|c|c|c|c|c|}
\hline Cells & Parameters & Groups & $0.07 \mathrm{mg} / \mathrm{l}$ & $0.10 \mathrm{mg} / \mathrm{l}$ & $0.15 \mathrm{mg} / \mathrm{l}$ \\
\hline \multirow{4}{*}{$\begin{array}{l}\text { Blood cells from gill } \\
\text { tissue }\end{array}$} & $\% \mathrm{MNC}$ & Exposed qp & $1.42 \pm 0.05^{a}$ & $3.37 \pm 0.09^{a}$ & $4.45 \pm 0.28^{a}$ \\
\hline & & Recovery qp & $0.47 \pm 0.05^{b}$ & $0.68 \pm 0.01^{b}$ & $1.2 \pm 0.05^{b}$ \\
\hline & $\% A C$ & Exposed gp & $28.8 \pm 0.89^{a}$ & $50.31 \pm 2.05^{a}$ & $63.71 \pm 0.84^{a}$ \\
\hline & & Recovery gp & $15.007 \pm 0.35^{b}$ & $19.48 \pm 0.38^{b}$ & $23.57 \pm 0.29^{b}$ \\
\hline \multirow{4}{*}{$\begin{array}{l}\text { Blood cells from kid- } \\
\text { ney tissue }\end{array}$} & $\% \mathrm{MNC}$ & Exposed gp & $1.26 \pm 0.02^{\mathrm{a}}$ & $2.14 \pm 0.19^{a}$ & $2.6 \pm 0.22^{a}$ \\
\hline & & Recovery gp & $0.41 \pm 0.02^{b}$ & $0.69 \pm 0.04^{b}$ & $1.01 \pm 0.05^{b}$ \\
\hline & $\% A C$ & Exposed gp & $38.87 \pm 0.57^{a}$ & $55.32 \pm 0.54^{a}$ & $53.38 \pm 1.76^{a}$ \\
\hline & & Recovery gp & $12.94 \pm 0.42^{b}$ & $14.64 \pm 0.42^{b}$ & $18.79 \pm 0.22^{b}$ \\
\hline
\end{tabular}

Values are given as mean \pm standard error. Different letters $(a, b)$ are significantly different (Tukey's test, $\mathrm{p} \leq 0.01)$ and signify the difference between exposed and recovery group.

treated with 4-NP at $0.15 \mathrm{mg} / \mathrm{l}$ concentration after 90 days of exposure.

Erythrocytes from kidney also showed higher mean values for MNC frequency after sub chronic exposure of 4-NP as compared to the MNC frequency in the control group. Among treated groups a 12.47 fold (highest value, $2.6 \pm 0.2$ ) increase was noted in MNC frequency as compared to the control group $(0.21 \pm 0.008$; Table 2$)$. AC frequency in kidney erythrocytes is found to be higher in groups treated with 4-NP as compared to both the control groups. Highest rate of AC frequency found in the kidney was $55.32 \%$, which was 6.95 folds higher compared to the control group. Highest effect was seen after treatment with a chemical concentration of $0.10 \mathrm{mg} / \mathrm{l}$ after 90 days exposure. Among both tissues, blood cells from gill showed more DNA damage as values of both parameters were found to be high in gill tissue.

MNC and AC frequencies in blood cells from gill and kidney of recovery period: Recovery 
pattern in MNC and AC frequencies in blood cells from gill and kidney of fish after 30 days is given in Table 3. At all the concentrations a significant reduction in the value of both the parameters, that is, MNC and AC frequencies (ANOVA and Tukey's test) was observed.

\section{DISCUSSION}

Various genotoxicants form strong covalent bonds with DNA, which result in mutation, and DNA adduct formation and prevent accurate DNA replication (Hartwell et al., 2000). Genotoxins affecting the germ cells (sperm and egg cells) can pass the genetic changes down to descendants (Hartwell et al., 2000). Studies pertaining to DNA damaging effects of xenoestrogens are important, because the changes may be the precursors of some of developmental abnormalities, and infertility (Atiezer et al., 2002). Micronuclei are induced by aneugenic agents, but it is also hypothesized that they may be induced by a clastogenic process (Anitha et al., 2000). The micronucleus assay is a cell cycle dependent assay that determines stable aberrations.

Micronucleus test has been used by a number of researchers for assessing genetic damage (Nwani et al., 2011; Kumar et al., 2013; Galindo et al., 2014). Several researchers have also identified other nuclear abnormalities, including nuclear bud, fragmented nucleus, vacuolated nucleus and binucleated cells as an indicator of genotoxicity (Ayllon and Garcia-Vazquez, 2000; Cavas and Ergene-Gozukara, 2003; Cavas et al., 2005; Talapatra and Banerjee 2007; Muranli and Guner, 2011). Although the mechanism of their formation has not yet been fully explained, according to Osman et al., (2014) nuclear abnormalities can be the precursor of $\mathrm{MN}$ and may be a process to eliminate amplified genes from the nucleus. These abnormalities are considered an indicator of genotoxic damage and therefore, may compliment the scoring of $\mathrm{MN}$ in routine genotoxicity surveys (Muranli and Guner, 2011; Serrano-Garcia and Montero- Montoya, 2001).

The different nuclear abnormalities may be the result of gene amplification and problem in chromosome attachment which may cumulatively lead to micronucleus,, binucleus, budded, notched or lobed nuclei (Bolongesi et al., 2006; Ergene et al., 2007). A number of vacolated cells were observed in the present study and the reason may be unequal distribution of hemoglobin and one of the common alterations observed in our study was swelled cells which may be due to the necrosis of cellular outline. Similar results were obtained by Mekkawy et al., (2011) after treating the fish $C$. galipinus with 4-NP. Six types of nuclear lesions were detected along with MN by Osman et al., (2011) who used Nile tilapia (O. niloticus) and African catfish (C. gariepinus) collected from the

\section{course of River Nile.}

Jiraungkoorskul et al., (2007) and Tsangaris et al., (2011) reported that MN study using erythrocytes is most sensitive as compared to information provided by gill, liver and fin cells. Palhares and Grisolia (2002) suggested that early erythrocytes show a higher sensitivity than the peripheral erythrocytes. On the other hand, several authors supported the use of renal and gill erythrocytes of fish (Ayllon and Garacia-Vazquez 2000; SerranoGarcia and Montero-Montoya 2001; Cavas et al., 2005). Talapatra and Banerjee (2007) used gill and kidney erythrocytes of Labeo bata from sewage fed fish farm. Fagr et al., (2008) suggested that gill is more sensitive than a hemopoietic tissue to the stressors for MN induction. Thus in the present study comparison has been done for the induction of MNC and other aberrant cells using blood cells from gill and blood cells from the kidney. We observed a higher frequency of MNC and a higher percentage of aberrant cells in blood cells from the kidney and gills of fish subjected to subchronic exposure as compared to controls. The effect of dose and duration of exposure was also found to be significant. Sharma and Chadha., (2016a) observed a significant increase in nuclear and cytoplasmic alteration in blood cells after acute exposure in C. punctatus after treatment with 4-nonylphenol. Similarly 4-nonylphenol is found to be immune-suppresser (Sharma et al., 2018).

The present study highlighted, inter tissue differences regarding the induction of MN. Gill tissue was found to show more effected as the values of both the parameters MNC and $A C$ are found to be higher in gill tissue.. Gill is the organ that comes into contact with contaminants prior to other organs and are also exposed constantly. So this might be the reason for a more severe damage in gill tissue. Various investigations were conducted where gill was found to be more sensitive than erythrocytes and kidney blood cells (Ali et al., 2009). A group of researchers had confirmed that gill tissue had a much higher sensitivity than other tissues (Ali et al., 2008, 2009; Sharma et al., 2007; Pandey et al., 2006; Nwani et al., 2010). The highest level of damage in gill and liver tissues of Zebra fish due to exposure to detergent was observed by Figueroa (2013). A large number of clastogenic and aneugenic compounds have been reported to cause nuclear lesions in kidney erythrocytes of fish. Barsiene et al., (2006) found significant induction of $\mathrm{MN}$ in peripheral blood and kidney erythrocytes. Furthermore, Rodriguez-Cea et al., (2003) tested the renal erythrocytes in brown trout inhabiting polluted area and found induction of micronuclei. These findings are further supported by Rybakovas et al., (2009) who tested peripheral blood and cephalic kidney erythrocytes for $\mathrm{MN}$, nuclear bud and fragmented 
apoptotic cells in Flounder (Platichthys flesus), Dab (Limanda limanda) and Cod (Gadus morhua), collected from 12 offshore sites from the Baltic Sea and 11 sites in the North. Fagr et al., (2008) reported a higher $\mathrm{MN}$ frequency in peripheral blood as compared to kidney erythrocytes when several fish were exposed to environmental stress in Egypt. In contrast, Palhares and Grisolia, (2002) did not find a significant difference between the micronucleated cells of the kidney and the gill erythrocytes. Similarly, Manna and Sudhukar (1986) found a nonsignificant increase in the frequency of micronuclei in gill and kidney blood cell after irradiation in two fish species. Furthermore Cavalcanto et al., (2008) reported a nonsignificant level of induction of MN in erythrocytes of fish $P$. lineatus after its exposure to herbicide roundup $®$ for 96 hours.

The possible reason for DNA damage in the present study may be its microtubular disruting activity or due to formation of reactive intermediates. Furthermore Vazquez-Duhalt et al., 2005 reported that nonylphenol induce DNA adduct formation and mutation or genomic rearrangements. Moreover increased DNA damage may also lead to apoptosis and apoptosis was observed in fish sertoli cells after nonylphenol exposure (Weber et al., 2002; Miura et al., 2005; Yi et al., 2009). Mekkawy et al., (2011) observed that 4-NP increased percentage of apoptotic cells in C. galipinus. The biotransformation of 4-nonylphenol may result in the production of intermediates which are highly reactive, toxic and can cause DNA breakage both directly and indirectly.

A significant decrease in DNA damage was found in all the tissues after the 30 day recovery period. Damage drop to control value suggested the possibility of a complete turnover of fish erythrocytes and other cells. The life span of erythrocytes in fish is between 1 and 3 months (Udroiu 2006). Sharma and Chadha, (2016 and 2018) found that fish C. punctatus retained its DNA integrity and hematological parameters to control value in blood cells from peripheral circulation after the 30 days recovery period when treated with 4nonylphenol. Similar results were found in Trout,s response (Bony et al., 2008) to vineyard pesticide, as well as in Carp and Bullheads (Pandrangi et al., 1995) and in Chub (Devaux et al., 1998). Guilherme et al., (2014) reported that blood cells of $A$. anguilla showed evident recovery at 14 days after exposure to herbicides based pesticide Roundup $囚$. Furthermore Marques et al., (2014) found that DNA integrity returned to the control level on the first day after cessation of exposure.

\section{Conclusion}

Both the tissues (gill and kidney) of fish C. punctatus tested showed DNA damage in time and dose dependent manner after sub chronic exposure.
Blood cells from gill were found to show higher damage as compared to blood cells from the kidney as the value of both the parameters MNC and AC were found higher in gill blood cells. The various regions of DNA damage, induced by NP may be due to its microtubule disrupting activity, DNA adduct formation, mutation and genomic rearrangement or may be due to the formation of toxic intermediates that may lead to DNA damage. A significant recovery from DNA damage found after 30 days suggest the strong capacity of $C$. punctatus to retain its DNA integrity.

\section{ACKNOWLEDGMENTS}

Authors are thankful to DST-PURSE for providing the grant.

\section{REFERENCES}

1. Ahel, M., Hrsak, D. and Giger, W. (1994). Aerobic transformation of short-chain alkylphenol polyethoxylates by mixed bacterial cultures. Archives of Environmental Contamination and Toxicology, 26, 540548.

2. Ali, D., Nagpure, N. S., Kumar, S., Kumar, R. and Kushwaha, B. (2008). Genotoxicity assessment of acute exposure of chlorpyriphos to freshwater fish, Channa punctatus (Bloch) using the micronucleus assay and alkaline single-cell gel electrophoresis. Chemosphere, 71, 1823-1831.

3. Ali, D., Nagpure, N. S., Kumar, S., Kumar, R., Kushwaha, B. and Lakra, W. S. (2009). Assessment of genotoxic and mutagenic effects of chlorpyriphos in freshwater fish, Channa punctatus (Bloch) using micronucleus assay and alkaline single-cell gel electrophoresis. Food and Chemical Toxicology, 47, 650-656.

4. Anitha, B., Chandra, N., Gopinath, P. M. and Durairaj, G. (2000). Genotoxicity evaluation of heat shock in gold fish Carassius auratus. Mutation Research, 469,1-8.

5. Atiezar, F. A., Billinghust, Z. and Depledge, M. H. (2002). 4-n-nonylphenol and 17- $\beta$ estradiol may induce common DNA effects in developing barnacle larvae. Environmental Pollution, 120, 735-738.

6. Ayllon, F. and Garcia-Vazquez, E. (2000). Induction of micronuclei and other nuclear abnormalities in European minnow Phoxinus phoxinus and mollie Poecilia latipinna: an assessment of the fish micronucleus test. Mutation Research, 467, 177-186.

7. Ayllon, F. and Garcia-Vazquez, E. (2001). Micronuclei and other nuclear lesions as genotoxicity indicators in rainbow trout Oncorhynchus mykiss. Ecotoxicology and Environmental Safety, 49, 221-225.

8. Baršiene, J., Dedonyte, V., Rybakovas, A., Andreikenaite, L. and Andersen, O. K. (2006). Investigation of micronuclei and other nuclear abnormalities in peripheral blood and kidney of marine fish treated with crude oil. Aquatic Toxicology, 78, S99-S104.f

9. Basak, P. K., and Konar, S. K. (1977). Estimation of safe concentration of insecticides, a new method tested on DDT and BHC. Inland Fisheries Society of India, 9, 9-29.

10.Bhatnagar, A., Yadav, A. S. and Cheema, N. (2016). Genotoxic effects of chlorpyrifos in freshwater fish Cirrhinus mrigala using micronucleus assay. Advanc- 
es in Biology. http:/dx.doi.org/10.1155/2016/9276963

11.Biney, C., D. Membe, T. W., Naeve, H., Nyakageni, B. and Saad, M. A. H. (1987). Scientific bases for pollution control in African inland waters. FAO fisheries, 369, 9-23.

12.Bolognesi, C., Perrone, E., Roggieri, P., Pampanin, D.M. and Sciutto, A. (2006). Assessment of micronuclei induction in peripheral erythrocytes of fish exposed to xenobiotics under controlled conditions. Aquatic Toxicology, 78, S93-S98.

13.Bony, S., Gillet, C., Bouchez, A., Margoum, C. and Devaux, A. (2008). Genotoxic pressure of vineyard pesticides in fish: Field and mesocosm surveys. Aquatic Toxicology, 89, 197-203.

14.Cavalcante, M., Martinez, R. and Sofia, S. (2008). Genotoxic effects of Roundup on the fish Prochilodus lineatus. Mutation Research, 655 (1-2), 41-46.

15.Çavas, T. and Ergene-Gözükara, S. (2003). Evaluation of the genotoxic potential of lambda-cyhalothrin using nuclear and nucleolar biomarkers on fish cells. Mutation Research, 534, 93-99.

16. Cavas, T., Garanko, N. N. and Arkhipchuk, V. V. (2005). Induction of micronuclei and binuclei in blood, gill and liver cells of fishes sub chronically exposed to cadmium chloride and copper sulphate. Food and Chemical Toxicology, 43 (4), 569-574.

17.Cox, C. (1996). Nonylphenol and related chemicals. Journal of Pesticide Reform Spring. 16 (1), (corrected 4/2003).

18.Devaux, A., Flammarion, P., Bernardon, V., Garric, J. and Monod, G. (1998). Monitoring of the chemical pollution of the River Rhône through the measurement of DNA damage and cytochrome P4501A induction in chub (Leuciscus cephalus). Marine Environmental Research, 46, 257-262.

19.Directive 2000/60/EC. (2000). Establishment and framework for community action in the field of water policy. Luxembourg, Luxembourg: European Parliament and Council of European Union.

20.EPA. 2010. Nonylphenol (NP) and Nonylphenal Ethoxylates (NPEs) Action Plan. February, 2014.

21.Ergene, S., Cavas, T., Celik, A., Ko"leli, N., Kaya, F. and Karahan, A. (2007). Monitoring of nuclear abnormalities in peripheral erythrocytes of three fish species from the Goksu Delta (Turkey): genotoxic damage in relation to water pollution. Ecotoxicology, 16, 385-391.

22.Fagr, A., El-shehawi, A. M. and Seehy, M. A. (2008). Micronucleus test in fish genome: a sensitive monitor for aquatic pollution. African Journal Biotechnology, 7 (5), 606-612.

23.Fiege, H., Voges, H. W., Hamamoto, T., Umemura, S., Iwata, T. and Miki, H. (2000). Phenol derivatives. Ullmann's Encyclopaedia of Industrial Chemistry. John-Wiley and Sons Inc.;

24. Figueroa, A. S. S. (2013). Evaluation of oxidative stress and genetic damage caused by detergents in the zebrafish Danio rerio (Cyprinidae). Comparative Biochemistry and Physiology Part A: Molecular and Integrative Physiology, 165 (4), 528-532.

25.Finney, D.J. (1971). Probit Analysis. Cambridge University Press, Cambridge. Pp.333.

26.Galindo, T. P. S., Rosário, I. R. andSilva, E. M. (2014). Micronucleus test in frillfin goby Bathygobius soporator (Valenciennes, 1873) from tide pools of Salvador City, Brazil. Brazil Journal of Aquatic Science Technology, 18 (1), 19-24.
27.Giger, W., Gabriel, F. L. P., Jonkers, N., Wettstein F. E. and Kohler, H. E. (2009). Environmental fate of phenol endocrine disruptors: field and laboratory studies. Philosophical Transaction of the Royal Society A. DOI: 10.1098/rsta.2009.0148

28.Guilherme, S., Santos, M. A., Gaivão, I. and Pacheco, M. (2014). Are DNA-damaging effects induced by herbicide formulations (Roundup®and Garlon $($ ) in fish transient and reversible upon cessation of exposure? Aquatic Toxicology, 155, 213-221.

29. Hamlin, H. J., Marciano, K.and Downs, C. A. (2015). Migration of nonylphenol from food-grade plastic is toxic to the coral reef fish species Pseudochromis fridmani. Chemosphere, 139, 223-8. Do: 10.1016/j. Chemosphere. 2015.06.032. Epub 2015 Jun 29

30. Hartwell. L. H., Hood, L., Goldberg, M. L., Reynolds, A. E., Silver, L. M. and Veres, R. C. (2000). Genetics: from Genes to Genomes. McGraw Hill Higher Education. ISBN 0-07-540923-2. Pp. 70-98, 144-169, 179 182, 341-351.

31.Jadhav, A. M. and Singare, P. U. (2015). Studies on water pollution due to toxic metals in Ulhas River flowing along the Dombivli City of Mumbai, India. International Letters of Natural Sciences, 38, 66-76.

32.Javed, M., Ahmad, I., Ahmad, A., Usmani, M. and Ahmad, M. (2016). Studies on the alterations in haematological indices, micronuclei induction and pathological marker enzyme activities in Channa punctatus (spotted snakehead) perciformes, channidae exposed to thermal power plant effluent. Springer Plus, 5: 761. http/-doi:10.1186/s40064-016-2478-9

33.Jiraungkoorskul, W., Sahaphong, S., Kosai, P. and Kim, M. (2007). Micronucleus test: The effect of ascorbic acid on cadmium exposure on fish (Puntius altus). Research Journal of Environmental Toxicology, 1, 27-36.

34.Johnson, A. C., Aerni, H. R., Gerritsen, A., Gibert, M., Giger, W., Hylland, K., Jurgens, M. and Nakari, T. (2005). Comparing steroid estrogen, and nonylphenol content across a range of European sewage plants with different treatment and management practices. Water Research, 39, 47-58.

35.Koh, Y. K. K., Lester, J. N. and Scrimshaw, M. D. (2005). Fate and behavior of alkyphenols and their polyethoxylates in an activated sludge plant. Bulletin of Environmental Contamination and Toxicology, 75, 1098-2006.

36.Kumar, A., Kesari, V. P. and Khan, P. K. (2013) Fish micronucleus assay to assess genotoxic potential of arsenic at its guideline exposure in aquatic environment. Biometals, 26, 337-346.

37.Lorenc, J. L., Scheffer, G., Alkylphenols, W. and Kirk -Othmer. (2003). Encyclopaedia of chemical technology. John Wiley and Sons Inc.;. (http://www.mrw. interscience.wiley.com/emrw/9780471238966/kirk/ article/alkylore.a01/ current/html).

38.Manna, G. K. and Sadhukhan, A. (1986). Use of cells of gill and kidney of tilapia fish in micronucleus test. Current Sciences, 55, 498-501.

39.Marques, A., Guilherme, S., Gaivao, I., Santo, M. A. and Pacheco, M. (2014). Progression of DNA damage induced by a glyphosate-based herbicide in fish (Anguilla anguilla) upon exposure and post exposure period. Insight into the mechanism of genotoxicity and DNA repair. Comaprative Biochemistry and Physiology part C: Toxicology and Pharmacology, 166, 126-133. 
40.Mekkawy, I. A., Mahmouda, U. M. and Sayeda, A. E. H. (2011). Effects of 4-nonylphenol on blood cells of the African catfish Clarias gariepinus (Burchell, 1822). Tissue and Cell, 43, 223- 229.

41.Miura, C., Takahashi, N., Michino, F. and Miura, T. (2005). The effect of paranonylphenol on Japanese eel (Anguilla japonica) spermatogenesis in vitro. Aquatic Toxicology, 71, 133-141.

42.Muranli, F. D. G. and Guner, U. (2011). Induction of micronuclei and nuclear abnormalities in erythrocytes of mosquito fish (Gambusia affinis) following exposure to the pyrethroid insecticide lamda- cyhalothrin. Mutation Research, 726, 104-108.

43.Nakada, N., Tanishima, T., Shinohara, H., Kiri, K. and Takada, H. (2006). Pharmaceutical chemicals and endocrine disrupters in municipal wastewater in Tokyo and their removal during activated sludge treatment. Water Research, 40, 297-303.

44.Nwani, C. D., Lakra W. S., Nagpure N. S., Kumar R., Kushwaha B. and Srivastava, S. K. (2010). Mutagenic and genotoxic effects of carbosulfan in freshwater fish, Channa punctatus (Bloch) using micronucleus assay and alkaline single-cell gel. Food and Chemical Toxicology, 48, 202-208.

45.Nwani, C. D., Nagpure, N. S., Kumar, R., Kushwaha, B., Kumar, P. and Lakra, W. S. (2011). Mutagenic and genotoxic assessment of atrazine-based herbicide to freshwater fish Channa punctatus (Bloch) using micronucleus test and single cell gel electrophoresis. Environmental Toxicology and Pharmacology, 31 (2), 314-322.

46.Nguyen, N. T., Hsieh, H. C., Lin, Y. W. and Huang, S. L. (2011). Analysis of bacterial degradation pathways for long-chain alkylphenols involving phenol hydroxylase, alkylphenol monooxygenase and catechol dioxygenase genes. Bioresource Technololgy, 102, 4232-4240.

47. Obiakor M. O., Nnabude P.C. and Ezeonyejiaku C. D. (2012). Eco-genotoxicology: Micronucleus assay in fish erythrocytes as in situ aquatic pollution biomarker: a review. Journal of Animal Sciences Advances, 2, 123-133.

48.Osman, A. G. M. (2014). Genotoxicity tests and their contributions in aquatic environmental research. Journal of Environmental protection 5: 1391-1399.

49. Osman, A. G., Abd-El-Reheema, A. M., Moustafa, M. A., Mahmoud, U. M., Abuel-Fadld, K. Y., and Kloas, W. (2011). In Situ Evaluation of the Genotoxic Potential of the River Nile: I. Micronucleus and Nuclear Lesion Tests of Erythrocytes of Oreochromis niloticus niloticus (Linnaeus, 1758) and Clarias gariepinus (Burchell, 1822). Toxicological and Environmental Chemistry, 93, 1002-1017.

50.Palhares, D.and Grisolia, C. K. (2002). Comparison between the micronucleus frequencies of kidney and gill erythrocytes in tilapia fish, following mitomycin $\mathrm{C}$ treatment. Genetics and Molecular Biology, 25 (3), 281-284.

51.Pandey, S., Nagpure, N. S., Kumar, R., Sharma, S., Srivastava, S. K. and Verma, M. S. (2006). Genotoxicity evaluation of acute doses of endosulfan to freshwater teleost Channa puctatus (Bloch) by alkaline single-cell gel electrophoresis. Ecotoxicology and Environmental Safety, 65, 56-61.

52.Pandrangi, R., Petras, M., Ralph, S. and Vrzoc, M. (1995). Alkaline single cell gel (Comet) assay and genotoxicity monitoring using bullheads and carp.
Environmental and Molecular Mutagenesis, 26, 345356.

53.Priac, A., Morin-Crini, N., Druart, C., Gavoille, S., Bradu, C., Lagarrigue, C., Torri, G., Winterton, P. and Crini, G. (2014). Alkylphenol and alkylphenol polyethoxylates in water and wastewater: A review of options for their elimination. Arabian Journal of Chemistry. http://dx.doi.org/10.1016/j.arabjc.2014.05.01

54.Rodriguez-Cea, A., Ayllon, F. and Garcia-Vazquez, E. (2003). Micronucleus test in freshwater fish species: an evaluation of its sensitivity for application in field surveys. Ecotoxicology and Environmental Safety, 56, 442-448.

55.Rybakovas, A., Barsiene, J. and Lang, T. (2009). Environmental genotoxicity and cyto- toxicity in the offshore zones of the Baltic and the North Seas. Marine Environmental Research, 68, 246-256.

56.Sandbacka, M., Christianson, I. and Isomaa, B. (2000). The acute toxicity of surfactants on the fish cells Daphnia magna and fish-a comparative study. Toxicology in Vitro, 14, 61-68

57.Serrano-García, L. and Montero-Montoya, R. (2001). Micronuclei and chromatin buds are the result of related genotoxic events. Environmental and Molecular Mutagenesis, 38 (1): 38-45.

58.Shao, B., Hu, J. and Yang, M. (2003). Nonylphenol ethoxylates and their biodegradation intermediates in water and sludge of a sewage treatment plant. Bulletin of Environmental Contamination and Toxicology, 21, 527-532.

59.Sharma, M. and Chadha, P. (2016b). 4-Nonylphenol induced DNA damage and repair in fish, Channa punctatus after subchronic exposure. Drug and Chemical Toxicity. http//:DOI: 10.1080 /0148 0545.2 016.1223096

60.Sharma, M. and Chadha, P. (2016a). Study of DNA damaging effect using 4-nonylphenol using erythrocytes from pheripheral circulation, gill and kidney of fish Channa punctatus. Journal of environmental Biology. 37 (2), 313-318.

61.Sharma, M. and Chadha, P. (2017). Widely used non -ionic surfactant 4-nonylphenol: showing genotoxic effect in various tissue of Channa punctatus. Environment Science and pollution Research. http://dx.DOI 10.1007/s11356-017-8759

62.Sharma, M. and Chadha, P. and Borah, M.K. (2018). Immune response in Channa punctatus after sub chronic 4-nonylphenol treatment and recovery. International journal of Fisheries and Aquatic Studies, 6 (4), 20-23.

63.Sharma, M., Chadha, P and Sharma, S. (2014) Acute and subchronic exposure of 4-nonylphenol to freshwater fish, Channa punctatus to evaluate its cytotoxicity. Biochemical and Cellular Archives, 14 (2), 363-367.

64.Sharma, S., Nagpure, N. S., Kumar, R., Pandey, S., Srivastava, S. K., Singh, P. J. and Mathur, P. K. (2007). Studies on the genotoxicity of endosulfan in different tissues of fresh water fish Mystus vittatus using the comet assay. Archives of Environmental Contamination and Toxicology, 53, 617-623.

65.Singare, P. U. and Dhabarde, S. S. (2014). Industrial pollution scenario due to discharge of waste water effluents along Dombivali Industrial Belt of Mumbai, India - a physico-chemical study. Interdisciplinary Environmental Review, 15 (1), 20-35.

66.Soares,. A, Guieysse, B., Jefferson, B., Cartmell, E. 
and Lester J. N. (2008) Nonylphenol in the environment: A critical review on occurrence, fate, toxicity and treatment in wastewaters. Environmental International, 34, 1033-1049.

67.Talapatra, S. N. and Banerjee, S. K. (2007) Detection of micronucleus and abnormal nucleus in erythrocytes from the gill and kidney of Labeo bata cultivated in sewage-fed fish farms. Food Chemicalo and Toxicology, 45, 210-215.

68.Talukdar, B., Kalita, H., Baishya, R. A., Basumatary, S. and Sarma, D. (2016) Evaluation of genetictoxicity caused by acidmine drainage of coal mines on fish fauna of Simsang River, Garohills, Meghalaya, India. Ecotoxicology and Environmental Safety, 131:65-71.

69.Tsangaris, C., Vergolyas, M., Fountoulaki, E. and Nizheradze, K. (2011) Oxidative stress and genotoxicity biomarker responses in grey mullet (Mugil cephalus) from a polluted environment in Saronikos Gulf, Greece. Archive of Environmental Contamination and Toxicology, 61, 482-490

70.Udroiu, I. (2006) The micronucleus test in piscine erythrocytes. Aquatic Toxicology, 79, 201-204.

71.Vazquez-Duhalt, R., Marquez-Rocha, F., Ponce, E., Licea, A. F. and Vaiana, M. T. (2005) Nonylphenol and integrated vision of a pollutant. Applied Ecology and Environment Research, 4, 1-25.

72. Vincent, M. D. V. and Sneddon, J. (2009) Nonylphenol: An overview and its determination in oysters and wastewaters and preliminary degradation results from laboratory experiments. Microchemical Journal. doi:10.1016/j.microc.2009.02.005.

73.Weber, D. N. and Spieler, R. E. (1994) Behavioral mechanisms of metal toxicity in fishes. In: Malins, D.C., Ostrander, G.K. (Eds.), Aquatic Toxicology: Molecular, Biochemical and Cellular Perspectives. CRC Press, London, UK. pp 421-467.

74.Wu, J., Yu, Z., Song, X., Wang, Y. and Cao, X. (2005) Comparative researches on effects of sodium dodecylbenze sulfonate and sodium dodecyl sulfate upon Lateolabrax japonicus bimoarker system. Environmental Toxicology and Pharmacology, 20, 465470.

75.Yi, G., Jiang, W., Yufeng, H., Sunan and Xiaodong, $H$. (2009) Nonylphenol induces apoptosis in rat testicular sertoli cells via endoplasmic reticulum stress. Toxicology Letters, 186, 84-95.

76.Ying, G. G., Williams, B. and Kookana, R. (2002) Environmental fate of alkylphenols and alkylphenol ethoxylates. Environmental International, 28, 215226. 